\title{
VII. Description of M. de Saussure's diaphanometer
}

\section{Dr. F.W. Aug. Murhard}

To cite this article: Dr. F.W. Aug. Murhard (1799) VII. Description of M. de Saussure's diaphanometer , Philosophical Magazine Series 1, 3:12, 377-381, DOI: $10.1080 / 14786449908677012$

To link to this article: http://dx.doi.org/10.1080/14786449908677012

册 Published online: 25 Jan 2010.

Submit your article to this journal $\sqsubset \pi$

Џll Article views: 3

Q View related articles $₫$ 
an ink of a red colour, like that of the rofa centifolia, which again difappeared when the paper became cold. I was not able to obtain it of a darker tint; but I muft confefs that I made only a few experiments for that purpofe, as I was fatisfied with the colour I had got.

VII. Defription of M. DE SAussune's Diaphanometer. By Dr. F. W. Aug. Murhard, of Gottingen. From Neues Journal der Phyfik, by Profeffor Gren. Vol. $I V$.

$\mathrm{T}$ HIS inftrument, firt defcribed by M. de Sauffure in the fourth volume of the Memoirs of the Royal Academy of Sciences at Turin, has fome refemblance to the cyanometer*, both in regard to its object and confruction. The principal difference is, that the latter fhews the whole effect of the vapour and evaporation diffufed throughout the atmofphere, from the eye of the obferver to the utmolt boundary of his view; while the diaphanometer is, on the other hand, defigned to thew the greatnels of the evaporations exifting in any limited part of the atmofphere which furrounds us.

The meafure of tranfparency in M. de Sauffure's inftrument, is founded on the proportion of the diftances at which determined objects ceafe to be vifible; and the point was to find objects, the difappearance of which, at a certain diftance, could be determined with the greateft accuracy. M. de Sauffure found that the moment of difappearance can be obferved much more accurately when a black object is placed on a white ground, than when a white object is placed on a black ground; that the accuracy was ftill greater when the obfervation was made in the fun, than in the fhade; and that even a ftill greater degree of accuracy was obtained, when the white fpace furrounding a black circle, was itfelf furrounded by a circle or ground of a dark colour: This laft

* An inftrument for determining the degree of the bluenefs of the heavens.

circumftance 
circumftance was particularly remarkable, and an obfervation quite new.

If a circle totally black, of about two lines in diameter, be faftened on the middle of a large fheet of paper or pafteboard, and if this paper or pafteboaid be placed in fuch a manner as to be expofed fully to the light or the fun, if you then approach it at the diftance of three or four feet, and afterwards gradually recede from it, keeping your eye conftantly directed towards the black circle, it will appear always to decreafe in fize the farther you retire from it, and at the diftance of 33 or 34 feet will have the appearance of a point. If you continue ftill to recede, you will fee it again enlarge itfelf; and it will feem to form a kind of cloud, the darknefs of which decreafes more and more according as the circumference becomes enlarged. The clond will appear ftill to increafe in fize, the farther you remove from it; but at length it will totally difappear. The moment of the difappearance, however, cannot be accurately afcertained; and the more experiments were repeated, the more were the refults different. This is an obfrvation perfectly accurate; and having myfelf made a feries of experiments under like circumftances, I am the more convinced of the truth of it.

M. de Sauflure, having reflected for a long time on the means of remedying this inconveniency, faw clearly, that, as long as this cloud took place, no accuracy could be obtained; and he difcovered that it appeared in confequence of the contraft formed by the white parts which were at the greateft diftance from the black circle. He thence concluded, that if the ground was left white near this circle, and the parts of the prafteboard at the greatef diftance from it were covered with a dark colour, the cloud would no longer be vifible, or at leaft almoft totally difappear.

This conjecture was confirmed by experiment. $M$. de Sauffure left a white fpace around the black circle equal in breadth to its diameter, by placing a circle of black paper a line in diameter on the middle of a white circle three lines 


\section{De Sauffure's Diapbanometer.}

in cliameter, fo that the black circle was only furrounded by a white ring a line in breadth. The whole was pafted upon a green ground. A green colour was chofen, becaufe it was dark enough to make the cloud difappear, and the eafieft to be procured.

The black circle, furrounded in this manner with white on a green ground, difappeared at a much lefs diftance, than when it was on a white ground of a large fize.

If a perfectly black circle, a line in diameter, be pafted on the middle of a white ground expofed to the open light, I can obferve it at the diftance of from 44 to 45 feet; but if this circle be furrounded by a white ring a line in breadth, while the reft of the ground is green, I lofe fight of it at the diftance of only ${ } 5_{i}$ - feet.

According to thefe principles M. de Sauffure delineated feveral black circles, the diameters of which increafed in a geometrical progreffion, the exponent of which was ${ }_{2}^{3}$. His fmalleft circle was $\frac{1}{5}$ or 0.2 of a line in diameter; the fecond, 0.3 ; the third, 0.45 ; and fo on to the fixteenth, which was 87.527 , or about 7 inches $3 \frac{1}{2}$ lines. Each of thefe circles was furrounded by a white ring, the breadth of which was equal to the diameter of the circle, and the whole was pafted on a green ground.

M. de Sauffure, for his experiments, felected a ftraight road or plain of about 12 or 1500 feet in circumference, which towards the North was bounded by trees or an afcent. Thole who repeat them, however, muft pay attention to the following remarks:-When a perfon retires backwards, keeping his eye conftantly fixed on the pafteboard, the eye becomes fatigucd, and foon ceafes to perccive the circle; as foon therefore as it ccafes to be difinguifhable, you muft fuffer your eyes to reft; not, however, by fhutting them, for they would when again opened be dazzled by the light, but by turning them gradually to fome lefs illuminated object in the horizon. When you have done this for about half a minute, 
and again directed your eyes to the pafteboard, the circle will be again vifible, and you muft continue to recede till it difappear once more. You muft then let your eyes reft a fecond time in order to look at the circle again, and continue in this manner till the circle becomes actually invifible.

If you wifh to find an accurate expreffion for the want of tranfparency, you mult employ a number of circles, the diameters of which increafe according to a certain progreffion, and a comparifon of the diftances at which they difappear will give the law according to which the tranfparency of the atmofphere decreafes at different diftances. If you wifh to compare the tranfparency of the atmofphere on two days, or in two different places, two circles will be fufficient for the experiment.

According to thefe principles, M. de Sauffure caufed to be prepared a piece of white linen cloth eight feet fquare. In the middle of this fquare be fewed a perfect circle, two feet in diameter, of beautiful black wool; around this circle he left a white ring two feet in breadth, and the reft of the fquare was covered with pale green. In the like manner, and of the fame materials, he prepared another fquare; which was, however, equal to only $x_{1^{2}}^{\frac{x}{2}}$ of the fize of the former, fo that each fide of it was 8 inches; the black circle in the middle was two inches in diameter, and the white fpace around the circle was 2 inches alfo.

If two fquares of this kind be fufpended vertically and parallel to each other, fo that they may be both illuminated in an equal degree by the fun; and if the atmofphere, at the moment when the experiment is made, be perfectly tranfparent, the circle of the large fquare, which is twelve times the fize of the other, mult be feen at twelve times the diftance. In M. de Sauffure's experiments the fmall circle difappeared at the diftance of $3 \mathrm{I}_{4}$ feet, and the large one at the diftance of 3588 feet, whereas it fhould have difappeared at the diftance of 3768 . The atmofphere, therefore, was not perfectly 
tranfparent. This arofe from the thin vapours which at that time were floating in it.

It is of great importance to afcertain the laws according to which the diftinctnefs of the vifibility of an object decreafes, either when the tranfparency of the medium through which the object is viewed is leffened, or when the thicknefs of the ftratum of the medium is increafed. Lambert, in his Photometry, has given an account of many ingenious experiments which he made on the decreafe of the quantity of light, by its propagation through a medium imperfectly tranfparent; but M. de Sauffure is the firft who has confidered the decreafe of the diftinctnefs with which an object is feen through fuch a medium at different diftances.

VIII. Hiftory of Aftronomy for the Year 1798. Read in the College de France, Nov. 20. By Jerome Latande, Infpector and Dean of the College, and formerly Director of the Obfervatory.

$\mathbf{B}_{\text {EING permitted for the tenth time to entertain the pub- }}$ lic with the progrefs of a fcience which has engaged my attention fifty years, I am happy in being able to announce things ftill more interefting than on the laft occafion; and, in the firft place, the conclufion of that grand operation the mealurement of the earth, or of $9^{\frac{2}{3}}$ degrees of the meridian from Dunkirk to Barcelona.

About the middle of January, Delambre, impatient to begin his fatiguinglabours, proceeded, notwithftanding the cold and the rain, to prepare a bafe from Lieurfaint to Melun; to complete the wooden pyramids, which were feventy feet in height, and to meafure the angles.

On the $24^{\text {th }}$ of February he had already finifhed feven ftations for the angles at the bafe: three men had been employed for fix weeks to cut down and remove from the high- 